\title{
DINAMIKA PENELITIAN MAHASISWA PENDIDIKAN MATEMATIKA DI PERGURUAN TINGGI ISLAM NEGERI ACEH
}

\author{
Cut Intan Salasiyah \\ Universitas Islam Negeri Ar-Raniry, JalanSyeikh Abdur Rauf ,Banda Aceh 23111, Indonesia \\ Email: cintansa@yahoo.co.id
}

\begin{abstract}
Abstrak
Penelitian ini dilakukan untuk mengetahui tema penelitian, pendekatan dan metode yang cendrung dilakukan oleh mahasiswa pendidikan matematika di PTIN Aceh. Penelitian dilakukan pada prodi pendidikan matematika di UIN Ar-Raniry dan IAIN Langsa. Jenis penelitian ini adalah penelitian kualitatif.Hasil penelitian menunjukkan bahwa tema penelitian yang paling diminati adalah pembelajaran matematika sebanyak $89 \%$; kemampuan berfikir, nalar, kognitif sebanyak $9 \%$ dan perancangan tugas, perangkat pembelajaran, penilaian sebanyak $2 \%$. Dilihat dari segi pendekatan penelitian, mahasiswa yang menggunakan pendekatan kuantitatif sebanyak $85 \%$, pendekatan kualitatif sebanyak $10 \%$ dan pendekatan kombinasi kuantitatif-kualitatif sebanyak $5 \%$. Dilihat dari segi metode penelitian yang digunakan adalah metode eksperimen sebanyak $45 \%$, metode deskriptif sebanyak 36\%, PTK sebanyak $15 \%$, dan metode pengembangan R\&D sebanyak $4 \%$. Hal lain yang diperoleh adalah terjadi pengulangan tema dan metode penelitian, namun yang lebih dominan adalah pada pengutipan dan pola analisis.
\end{abstract}

\section{Kata kunci: Dinamika Penelitian, Isu Penelitian, Tema Penelitian}

\begin{abstract}
This research was conducted to find out the research themes, approaches and methods that tend to be carried out by mathematics education students at PTIN Aceh. The study was carried out at the study program of mathematics education at UIN Ar-Raniry and IAIN Langsa. This type of research is qualitative research. The results showed that the most popular research theme was mathematics learning as much as $89 \%$; thinking skills, reasoning, cognitive as much as $9 \%$ and design tasks, learning tools, valuation as much as $2 \%$. In terms of the research approaches, students who used a quantitative approach are $85 \%$, a qualitative approach is $10 \%$ and a quantitative-qualitative combination approach is $5 \%$. In terms of the research methods used are the experimental method as much as $45 \%$, descriptive method as much as $36 \%$, PTK as much as $15 \%$, and R \& D development methods as much as $4 \%$. Other aspects obtained arethe repetition of research themes and methods, however, the more dominant ones are quotations and analysis patterns.
\end{abstract}

Keywords: Research Dynamics, Research Issues, Research Themes

\section{PENDAHULUAN}

Penelitian pendidikan matematika mempunyai peran penting dalam upaya peningkatan kualitas pembelajaran matematika. Para peneliti pada bidang pendidikan matematika termasuk dosen, guru, mahasiswa dan praktisi lainnya, merupakan pihak yang peduli terhadap permasalahan dan pengembangan kualitas pendidikan matematika. Berhubungan dengan kapasitas para peneliti, maka maksud dan tujuan penelitian pun akan memunculkankeberagaman.

Skripsi merupakan sebuah laporan penelitian sebagai tugas akhir dan menjadi tolak ukur mahasiswa untuk menyelesaikan jenjang pendidikan di Strata 1. Ada beberapa mata kuliah yang harus dilalui oleh mahasiswa untuk mendukung penulisan skripsi, misalnya ilmu pendidikan, statistik, metode penelitian, pengelohan data, penelitian pendidikan matematika, seminar proposal matematika, dan lain-lain. Jadi idealnya secara teoritis mahasiswa mampu melakukan suatu penelitian sesuai tema 
keilmuan yang ditempuh. Layaknya sebuah penelitian, skripsi harus memenuhi persyaratan ilmiah, sudah semestinya hasil penelitian ini dapat barmanfaat bagi pengembangan keilmuan pada program studi yang ada. Contoh sederhana adalah mahasiswa Fakultas Tarbiyah dan Keguruan yang mempunyai kewajiban menulis skripsi bertema pendidikan, sehingga akan menghasilkan atau mengembangkan ilmu-ilmu pendidikan.

Berdasarkan pengalaman peneliti selama membimbing dan menguji penelitian skripsi mahasiswa, menunjukkan bahwa fokus penelitian pendidikan matematika mahasiswa masih relatif mengerucut pada tema tertentu misalnya penerapan suatu model pembelajaran. Mahasiswa cenderung mempunyai ketergantungan terhadap issue pendidikan yang telah diteliti mahasiswa pada tahun angkatan sebelumnya. Umumnya yang dilakukan adalah penelitian sejenis, hanya beda sampel/subjek penelitian saja. Selain itu, untuk mengkonfirmasi hal tersebut peneliti juga melakukan preliminary research menemukan bahwa banyak kasus pada skripsi terjadi pengulangan-pengulangan tema tulisan. Adapun isi dan analisis juga banyak kesamaan, baik berupa cara mengungkapan data, penggunaan teori, pengutipan serta daftar kutipan. Ketergantungan ini akan mengurangi manfaat dan makna suatu penelitian. Hal tersebut akan menyebabkan mahasiswa kurang menguasai keterampilan meneliti. Disamping itu, tema-tema penelitian penting lainnya akan kurang tergali.

Berdasarkan Journal for Research in Mathematics Education (JRME) (dalam Tatag,2017), untuk tahun 2009-2014 topik-topik yang diterbitkan adalah sebagai berikut; Pembuktian, bukti, dan argumentasi; Aljabar dan pemahamannya, Pengembangan profesi guru, pengawas, dan kepala sekolah, lesson study; Konsepsi guru dan pengetahuannya, pengetahuan pedagogik guru, keyakinan, kesadaran guru, gesture; Perbedaan gender, suku, sosiopolitikal, bahasa, keadilan sosial, kesamaan; kekuasaan, identitas; Pemecahan masalah, masalah divergen, representasi; Peran teknologi, game online, Kognisi, model mental, berpikir, penalaran, penalaran kuantitatif, konsepsi siswa; Pembelajaran berbasis Masalah, proses pembelajaran dan perancangannya; Geometri, pengukuran, pengajaran geometri; Perancangan tugas, perangkat pembelajaran, penilaian, asessmen; Kesamaan kesempatan belajar, aspek-aspek social; Pembelajaran matematik untuk anak luar biasa (disabilities); Bilangan dan pemahamannya, bilangan negatif pecahan; Perbandingan kurikulum; Kreativitas dan keberbakatan; Sejarah matematika.

Melihat banyaknya tema penelitian pendidikan matematika yang dapat dikaji, maka diperlukan berbagai upaya untuk memberikan arah yang jelas bagi proses pengembangan kemampuan mahasiswa dalam meneliti. Agar kecenderungan duplikasi penelitian bisa dikendalikan dan meningkatkan pengetahuan tentang tema dan cara meneliti akan lebih baik dan beragam.

Berdasarkan fenomena di atas, maka penelitian ini menggali trend isu/ tema penelitian, pendekatan dan metode yang cendrung dilakukan oleh mahasiswa pendidikan matematika di PTIN Aceh. Upaya ini perlu dilakukan sebagai langkah evaluasi tentang penguasaan mahasiswa tentang penelitiannya, pada aspek tema dan metodologis. Di samping itu, dapat memetakan tentang kajiankajian penelitian mahasiswa yang sudah banyak dilakukan, dan yang belum dioptimalkan sehingga 
dapat diupayakan langkah peningkatan pengetahuan teoritis dan aplikatif bidang penelitian mahasiswa.

\section{METODE PENELITIAN}

Penelitian ini mendeskripsikan dinamika penelitian pendidikan matematika pada skripsi mahasiswa. Jenis penelitian ini adalah penelitian kualitatif. Hasil penelitian dipaparkan secara deskriptif kuantitatif, dimana gambaran hasil penelitian diuraikan dengan kata-kata dan juga disajikan dalam bentuk tabel dan diagram.

Penelitian ini menggunakan sumber primer berupa data hasil penelitian atau skripsi mahasiswa Pendidikan Matematika Fakultas Tarbiyah dan Keguruan Universitas Islam Negeri Ar-Raniry Banda Aceh, dan Fakultas Ilmu Tarbiyah dan Keguruan Institut Agama Islam NegerI Langsa. Pemilihan skripsi Pendidikan Matematika pada dua PTKIN tersebut didasarkan dengan pertimbangan bahwa prodi Pendidikan

Matematika di dua PTKIN tersebut sudah cukup lama dan sudah banyak melahirkan sarjana pendidikan matematika. Pengambilan subjek pada periode tahun 2015-2017, dengan pertimbangan bahwa periode tahun tersebut dianggap cukup merepresentasikan kondisi penulisan skripsi di PTKIN tersebut. Peneliti mengambil data penelitian di Perpustakaan Mini Prodi Pendidikan Matematika FTK UIN Ar-Raniry Banda Aceh., dan di Perpustakaan Induk IAIN Langsa

Teknik pengumpulan data adalah dokumentasi yang digunakan untuk menggali informasi tentang dinamisasi penelitian pendidikan matematika pada skripsi mahasiswa Prodi Pendidikan Matematika. Seluruh data yang terkumpul dianalisis secara deskriptif kuantitatif. Pertama memadukan dan menggeneralisasikan hasil data dalam bentuk kalimat deskriptif secara terperinci dan apa adanya. Kemudian data yang diperoleh akan dianalisis menggunakan model persentase dari tiap parameter yang diukur dalam penelitian. Serta data yang telah diolah akan ditampilkan dalam bentuk tabel dan diagram untuk mempermudah dalam membacanya serta dengan mendeskripsikannya. Kemudian terhadap data tertulis dilakukan analisis isi (content analisys), dan verifikasi serta interpretasi. Untuk data yang dianggap mempunyai banyak kesamaan isi dan bentuknya maka juga dianalisis perbandingan dengan menggunakan pendekatan analisis isi (content analysis) terhadap data tertulis

\section{HASIL PENELITIAN DAN PEMBAHASAN}

Dinamika penelitian yang dideskripsikan adalah tema penelitian skripsi Pendidikan Matematika, pendekatan penelitian, dan metode penelitian yang dipilih mahasiswa Pendidikan Matematika selama tiga tahun terakhir 2015 s/d 2017 pada dua perguruan tinggi negeri yang mempresentasikan PTKIN yang ada di Aceh . 


\section{Tema Penelitian Mahasiswa}

Tema penelitian yang diminati oleh mahasiswa adalah tema pertama,pengajaran atau pembelajaran matematika;tema kedua, kemampuan kognitif siswa, penalaran, berpikir;dan tema ketiga, perancangan tugas, perangkat pembelajaran, penilaian, assesmen.

Secara spesifik, dapat dijelaskan bahwa tema pengajaran atau pembelajaran matematika berkisar tentang penerapan/ implementasi/ pengaruh sebuah model, strategi, metode, pendekatan, atau treatment (perlakuan) lainnya yang diberikan kepada siswa sebagai alternatif untuk memecahkan masalah. Sedangkan tema kemampuan kognitif siswa, penalaran, berpikir seperti menyangkut dengan nalar atau proses berpikir atau profil kemampuan siswa dalam memecahkan masalah. Tema yang ketiga yang dipilih oleh mahasiswa adalah perancangan tugas, perangkat pembelajaran, penilaian seperti penelitian mengembangan perangkat pembelajaran seperti modul, atau lembar kerja siswa.

Skripsi penelitian Pendidikan Matenatika yang ada dipustaka Prodi Pendidikan Matematika FTK UIN Ar-Raniry selama tiga tahun terakhir berjumlah 111 karya tulis. Untuk tahun 2015 berjumlah 34, tahun 2016 sebanyak 66 skripsi, sedangkan tahun 2017 sampai bulan Oktober skripsi yang ada dipustaka prodi berjumlah ada 11.

Tabel 1. Tema Penelitian Mahasiswa UIN Ar-Raniry

\begin{tabular}{|c|c|c|c|}
\hline No & Tema penelitian & Jumlah & Persentase \\
\hline \multirow{3}{*}{$\begin{array}{l}1 . \\
2 .\end{array}$} & Pembelajaran, Pengajaran & 97 & $87,4 \%$ \\
\hline & Kemampuan Kognitif & 10 & $9 \%$ \\
\hline & Penalaran, Berpikir, & & \\
\hline \multirow[t]{2}{*}{3.} & PerancanganTugas, & & \\
\hline & $\begin{array}{l}\text { PerangkatPembelajaran, } \\
\text { Penilaian, Assesmen }\end{array}$ & 4 & $3,6 \%$ \\
\hline Total & & 111 & $100 \%$ \\
\hline
\end{tabular}

Tabel 1. di atas menunjukkan bahwa penelitian skripsi pendidikan matematika pada tahun 2015,2016, dan 2017 didominasi oleh isue atau tema pengajaran, atau pembelajaran matematika, yaitu sebanyak $87,4 \%$. Sedangkan kedua tema lainnya persentase relatif sedikit. Tema penalaran, berpikir ada $9 \%$. Sedangkan untuk tema perancangan tugas, perangkat pembelajaran,penilaian sebanyak 3,6 $\%$.

Jumlah skripsi penelitian Pendidikan Matematika di IAIN Langsa tahun 2015 berjumlah 115 skripsi, tahun 2016 sebanyak 64 dan tahun 2017 sebanyak 9 skripsi. Gambaran ini dapat dilihat pada tabel berikut. 
Tabel 2 Tema Penelitian Mahasiswa IAIN Langsa

\begin{tabular}{|c|c|c|c|}
\hline No & Bidangpenelitian & Jumlah & Persentase \\
\hline 1. & Pembelajaran, Pengajaran & 168 & $89,36 \%$ \\
\hline 2. & $\begin{array}{l}\text { Kemampuan Kognitif } \\
\text { Penalaran, Berpikir, }\end{array}$ & 18 & $9,57 \%$ \\
\hline 3. & $\begin{array}{l}\text { Perancangan Tugas, } \\
\text { Perangkat Pembelajaran, } \\
\text { Penilaian, Assesmen }\end{array}$ & 2 & $1,06 \%$ \\
\hline Total & & 188 & $100 \%$ \\
\hline
\end{tabular}

Tema penelitian skripsi mahasiswa Prodi Pendidikan Matematika di IAIN Langsa juga didominasi oleh tema pembelajaran matematika sebanyak 89,36 \% dari 188 skripsi mahasiswa. Kemudian tema Kemampuan kognitif siswa dan Perancangan tugas, atau perangkat pembelajaran masing-masing $9,57 \%$ dan $1,06 \%$.

Tema penelitian secara keseluruhan yang diwakili oleh dua PTKIN di Aceh, terdiri dari 229 skripsi terlihat pada diagram berikut.

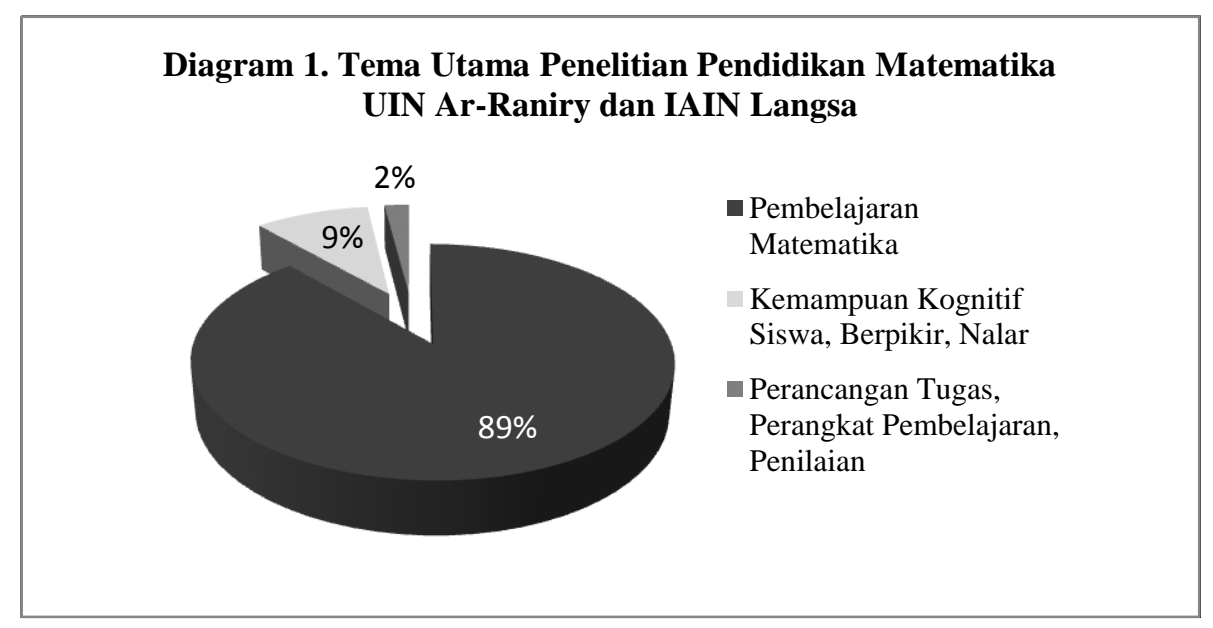

Tema penelitian yang paling diminati adalah tema pembelajaran matematika sebanyak $89 \%$, kemampuan kognitif siswa, berpikir, nalar ada 9\%, dan $2 \%$ mahasiswa memilih tema perancangan tugas, perangkat pembelajaran, penilaian.

\section{Pendekatan Penelitian Mahasiswa}

Jenis pendekatan penelitian yang dipilih Mahasiswa Prodi Pendidikan Matematika di UIN ArRaniry dan IAIN Langsa yang dilakukan oleh mahasiswa dikelompokkan menjadi tiga yaitu pendekatan kualitatif, kuantitatif, serta kombinasi. 
Tabel 3.Pendekatan Penelitian MahasiswaUIN Ar-Raniry

\begin{tabular}{|c|c|c|c|}
\hline No & Pendekata Penelitian & Jumlah & Persentase \\
\hline 1. & Kuantitatif & 90 & $81,08 \%$ \\
\hline 2. & Kualitatif & 12 & $10,82 \%$ \\
\hline 3. & Kombinasi & 9 & $8,10 \%$ \\
\hline Total & & 111 & $100 \%$ \\
\hline
\end{tabular}

Data tabel di atas menginformasikan bahwa hampir semua mahasiswa Prodi Pendidikan Matematika UIN Ar-Raniry memilih pendekatan kuantitatif dalam penulisan skripsi, yaitu 81,08\%. Sisanya $10,82 \%$ memilih pendekatan kualitatif dan $8,10 \%$ skripsi mahasiswa adalah menggunakan pendekatan kombinasi dari kuantitif dan kualitatif.

Tabel 4. Pendekatan Penelitian Mahasiswa IAIN Langsa

\begin{tabular}{|c|c|c|c|}
\hline No & Pendekata Penelitian & Jumlah & Persentase \\
\hline 1. & Kuantitatif & 165 & $87,76 \%$ \\
\hline 2. & Kualitatif & 16 & $8,51 \%$ \\
\hline 3. & Kombinasi & 7 & $3,72 \%$ \\
\hline Total & & 188 & $100 \%$ \\
\hline
\end{tabular}

Tabel di atas menunjukkan bahwa jenis pendekatan penelitian yang digunakan mahasiswa prodi Pendidikan Matematika IAIN Langsa yang paling banyak adalah pendekatan kuantitaif, yaitu 87,76 $\%$. Pendekatan kualitatif hanya $8,51 \%$, dan $3,72 \%$ lagi mahasiswa menggunakan pendekatan kombinasi.

Diagram berikut menunjukkan jenis pendekatan yang dilaksanakan oleh mahasiswa keseluruhan.

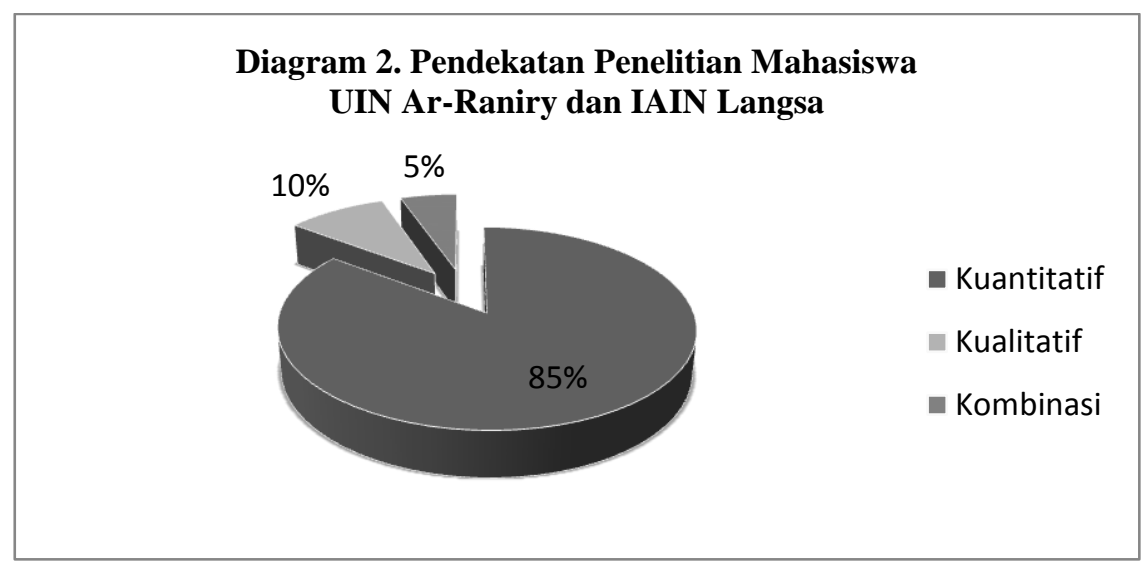

Mahasiswa Pendidikan Matematika menyusun skripsi cenderung memilih pendekatan kuantitatif sebanyak 85\%, memilih pendekatan kualitatif sebanyak10\%, dan sebanyak 5\% mahasiswa memilih pendekatan kombinasi kuantitatif dan kualitatif.

\section{Metode Penelitian Mahasiswa}

Terdapat 4 macam metode penelitian yang dipilih mahasiswa Pendidikan Matematika PTIN di Aceh dalam melaksanakan penelitian skripsi tahun 2015-2017. 
Tabel 5 . Metode Penelitian Mahasiswa FTK UIN Ar-Raniry

\begin{tabular}{clcc}
\hline No & Metode penelitian & Jumlah & Persentase \\
\hline 1. & PTK & 31 & 27.93 \\
2. & Eksperimen & 39 & 35.14 \\
3. & Deskriptif & 32 & 28.83 \\
4. & R\&D & 9 & 8.10 \\
\hline Total & & 111 & 100 \\
\hline
\end{tabular}

Data di atas menjelaskan bahwa tiga metode penelitian Pendidikan Matematika yang dipilih mahasiswa UIN Ar-Raniry relatif sama,yaitu PTK terdapat 27,93 \%, Eksperimen 35,14\%, dan ada $28.83 \%$ mahasiswa yang memilih metode deskriptif. Sisanya hanya $8,10 \%$ mahasiswa yang memilih metode pengembangan $(R \& D)$.

Tabel 6 . Metode Penelitian Mahasiswa IAIN Langsa

\begin{tabular}{clcc}
\hline No & Metodepenelitian & Jumlah & Persentase \\
\hline 1. & PTK & 15 & $7.98 \%$ \\
2. & Eksperimen & 96 & $51.06 \%$ \\
3. & Deskriptif & 74 & $39.36 \%$ \\
4. & R\&D & 3 & $1.60 \%$ \\
\hline Total & & 188 & $100 \%$ \\
\hline
\end{tabular}

Berdasarkan tabel 6, dapat dilihat bahwa mahasiswa Pendidikan Matematika IAIN Langsa cenderung memilih metode eksperimen sebanyak $51.06 \%$, selebihnya metode deskriptif sebanyak $39,36 \%$, metode PTK sebanyak 7,98\% dan R \& D 1,60\%.

Beberapa metode penelitian yang dipilih oleh mahasiswa pendidikan matematika dalam melaksanakan skripsi di Aceh yang dipresentasikan oleh dua PTIN UIN Ar-Raniry dan IAIN Langsa. Proporsi persentase yang lebih lengkap dapat dilihat pada diagram 3 di bawah ini.

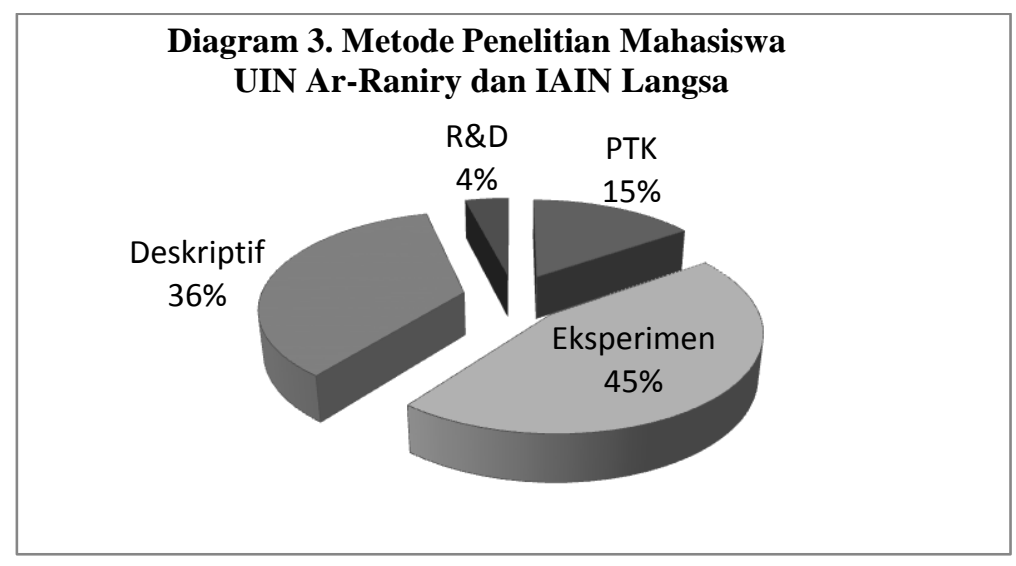

Diagram di atas menginformasikan bahwa variasi metode penelitian yang diminati mahasiswa Pendidikan Matematika dari tahun 2015-2017 di Aceh adalah metode eksperimen sebanyak 45\%, metode deskriptif sebanyak $36 \%$, PTK sebanyak 15\%, dan R\&D sebanyak 4\%. 
Berdasarkan hasil analisis dokumen skripsi Pendidikan Matematika FTK UIN Ar-Raniry dan FTIK IAIN Langsa tahun 2015 sampai 2017 diperoleh gambaran sebagai berikut.

Pertama, Pengulangan tema penelitian. Beberapa skripsi memiliki tema yang sama, hanya berbeda lokasi (sampel/subjek) saja, sementara alasan atau latar belakang masalah kurang sesuai dengan strategi yang ditawarkan. Penggunaan teori yang terkait tema yang dibahas pun banyak kesamaan.

Kedua, pengutipan dan penulisan redaksi kalimat yang relatif sama, terutama pada bagian latar belakang, metode penelitian dan kajian teori. Beberapa skripsi menunjukkan bahwa pengungkapan dan penulisan kalimat yang sama, baik isinya maupun cara menyampaikannya. Adanya kecenderungan ini mengindikasikan bahwa terdapat proses duplikasi. Dengan kata lain terdapat proses peniruan yang dilakukan angkatan terakhir terhadap para pendahulunya angkatan sebelumnya. Bahasa atau redaksi yang sebelumnya ditiru dan diketik ulang oleh adik angkatan tanpa melihat kesesuaian antara apa yang ditirunya dengan masalah atau tema serta metode yang seharusnya dipergunakan dalam penelitian. Pengulangan penulisan ini memberikan beberapa asumsi bahwa ketidakpedulian beberapa mahasiswa terhadap metode penelitian yang sesuai yang seharusnya dipakai dalam meneliti. Kemudian mahasiswa kurang menguasai metode penelitian sehingga mendorongnya untuk mencontoh apa saja yang tertulis dan dipakai oleh angkatan sebelumnya.

Ketiga, kesamaan pola analisis data pada skripsi dengan tema sama. Beberapa skripsi mahasiswa menggambarkan ada kesamaan cara analisis antara skripsi-skripsi yang bertema sama. Ini dapat diasumsikan bahwa ada kemungkinan terjadi pengulangan penulisan atau adanya pemindahan tulisan sebelumnya. Keempat, pembahasan yang mengambang. Pada bagian pembahasan, seharusnya dimasukkan atau diinterpretasi hasil analisis penelitian, tidak hanya diisi oleh teori pendapat ahli. Adanya hal ini nampaknya sudah dianggap cukup dan bisa menuntaskan jawaban penelitian atau pertanyaan penelitian. Kelima, referensi lama. Daftar pustaka dari banyak skripsi bertahun 2000 atau 2010. Ini juga menggambarkan bahwa perkembangan minat baca mahasiswa masih rendah.

Mencermati beberapa hal di atas, maka perlu kiranya memberikankan perhatian lebih baik terkait penelitian mahasiswa, diantaranya tentang perkuliahan metodologi penelitian, analisis statistik,dan mata kuliah penunjang lainnya. Mata kuliah-mata kuliah tersebut hendaknya diberikan lebih intens dan aplikatif. Mahasiswa perlu dilibatkan dalam penelitian atau pengkajian masalah pendidikan matematika Selain itu penambahan buku-buku referensi terbaru untuk menunjang penelitian pendidikan matematika.

\section{KESIMPULAN}

Berdasarkan pembahasan di atas diperoleh kesimpulan tentang pengkajian dinamika penelitian mahasiswa pendidikan matematika pada tahun 2015-2017 sebagai berikut. Pertama, tema penelitian pendidikan matematika yang paling diminati adalah tema pembelajaran matematika sebanyak 89\%, tema kamampuan kognitif siswa, berpikir, nalar sebanyak 9\%, dan tema perancangan tugas, perangkat pembelajaran, penilaian sebanyak $2 \%$. Kedua, pendekatan penelitian yang sering digunakan 
adalah pendekatan kuantitatif sebanyak $85 \%$, pendekatan kualitatif sebanyak $10 \%$, pendekatan kombinasi kuantitatif dan kualitatif sebanyak 5\%. Metode penelitian yang yang sering digunakan adalahpenelitian eksperimen sebanyak 45\%, metode deskriptif sebanyak 36\%, penelitian PTK15\%, penelitian pengembangan R \& D sebanyak $4 \%$.

Beberapa hal yang sering terjadi dalam penulisan skripsi mahasiswa di antaranya pengulangan tema dan metode penelitian tampa alasan yang tepat, adanya pengutipan paragraf/kalimat yang sama antar skripsi, pola analisis data yang sama antar skripsi, pembahasan yang mengambang dan menggunakan referensi lama.

\section{REFERENSI}

Arikunto, Suharsimi. (2010). Prosedur Penelitian, Suatu Pendekatan Praktek, Jakarta: Rineka Cipta.

Darmadi, Hamid.(2011), Metode Penelitian Pendidikan, Jakarta: Alfabeta.

Iriawan, Ida. (2013), Analisis Kecenderungan Penelitian Skripsi Mahasiswa Prodi Pendidikan Matematika STKIP PGRI Pacitan. Yogyakarta, Prosiding Seminar Nasional Matematika dan Pendidikan Matematika FMIPA UNY ISBN : 978-979-16353-9-4

Hasanah, Mila. (2014), Analisis Kecenderungan Penelitian Skripsi Mahasiswa PGMI Sebagai Revitalisasi Bidang Keahlian Guru MI. AL-ADZKA,Jurnal Ilmiah Pendidikan Guru Madrasah Ibtidaiyah, Volume IV, Nomor 01

Setyosari, Punaji. (2010), Metode Penelitian Pendidikan dan Pengembangan, Jakarta: Kencana Prenada MediaGroup

Sugiono. (2009), Metode Penelitian Pendidikan, Pendekatan Kuantitatif, Kualitatif, dan R\&D, Bandung:Alfabeta

Siswono,TatagY. E.Penelitian Pendidikan Matematika., Surabaya: UNESA University Press,di akses http://www.mathematics.web.id/2016/05/penelitian-pendidikan-matematika-bytatag-yes.html, tanggal 18 Maret 2017 pukul 17:00

Siswono, Tatag Y. E. Makalah Kecenderungan Penelitian Pendidikan Matematika Terkini, diakses dari https://www.academia.edu/pada tanggal 20 Maret 2017 pukul 10:00. Hlm 1 
